International Journal of Engineering \& Technology, $7(4.20)(2018) 67-71$
International Journal of Engineering \& Technology
SPC
Website: www.sciencepubco.com/index.php/IJET
Research paper

\title{
Influence of Pottery Clay in Cement Mortar and Concrete Mixture: A Review
}

\author{
Doha M. Al Saffar ${ }^{*}$ Bassam A. Tayeh ${ }^{2}$ \\ ${ }^{1}$ Civil Engineering Department, Al Mansour University College, Baghdad, Iraq, \\ ${ }^{2}$ Civil Engineering Department, The Islamic University of Gaza, Gaza, Palestine \\ *Corresponding author E-mail:doha.mothefer@muc.edu.iq
}

\begin{abstract}
Solid generation has brought about numerous natural issues, for example, CO2 discharge. An option eco-accommodating concrete, known as green cement, ought to be investigated. Squander materials from marine waste, ventures, and farming can be reused to deliver green cement. This paper displays a survey of ongoing advancement identified with the attainability of utilizing stoneware earth in solid blend. The report centers around the likelihood of using dirt block squander as fractional substitution for Portland bond in cement and the properties of crisp and solidified concrete, for example, usefulness, thickness, quality, and microstructure. This paper ought to give new data on the uses of greener and supportable stoneware mud concrete. Past investigations showed that the ideal rate for supplanting Portland concrete with earthenware dirt ran somewhere in the range of $10 \mathrm{wt} \%$ and $30 \mathrm{wt} \%$.
\end{abstract}

Keywords: Clay brick; flexural strength; Pottery clay; Split tensile strength; Compressive strength; mechanical property

\section{Introduction}

Concrete is the most widely used material worldwide. As the demand for the construction industry escalates, the need for concrete increases. This phenomenon leads to the increasing demand for cement. Concrete production causes $\mathrm{CO}_{2}$ emission of approximately $2 \%-37 \%$, which is a high record for the past three years $[1,2]$. The increasing revolution for an eco-friendly concrete requires necessitates more pollution control and efficient and effective use of waste material resources from different industries. Several waste materials with Pozzolanic properties contain high proportions of silica $\mathrm{SiO}_{2}$ and alumina $\mathrm{Al}_{2} \mathrm{O}_{3}$ [3], e.g., rice husk ash, which showed the development of concrete strength [4-15]. Saw dust ash is used to produce green concrete and solved many environmental problems, especially in timber industries [16-23]. Iron powder [24-35], glass powder [36-43], and pottery clay (PC) [4463] have recently become popular materials which enhanced the production of green concrete and simultaneously reduced the cost in construction industries.

Clay brick (CB) is one of the oldest and most durable construction tools. This method is currently used extensively to restore historical structures. Therefore, continuous production of $\mathrm{CB}$ is necessary [53]. Fired clay or PC is soil material burned at $600-900{ }^{\circ} \mathrm{C}$. The PC waste is an appropriate material to produce sustainable mortar or concrete [54]. This paper explains the chemical composition of fired clay powder or PC and its effect on fresh and hardened properties of mortar and concrete.

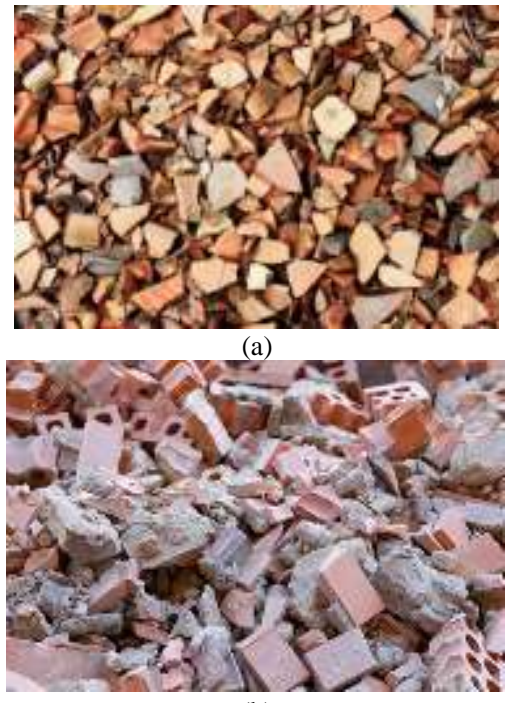

(b)

Fig. 1: (a) Waste Pottery clay, (b) Concrete building waste bricks Sydney city rubbish removal [65].

\section{Previous studies on $\mathrm{CB}$ in concrete and mor- tar}

\subsection{Chemical composition of $\mathrm{CB}$ waste}

Previous studies documented the chemical composition of different clay minerals considered as supplementary cementitious materials $[47,48,51,52,54]$. Four clay samples were collected from Kaikalathur (KA-II), Kuchipalayam (KP), Anangoor (AN), and Oviyampalayam (OP) of Tamilnadu. The clay materials were dried under the sun and then crushed to pass through $600 \mu \mathrm{m}$ sieve. 
The chemical analytical results showed that the $\mathrm{SiO}_{2}$ content in sample KA-II (54.13\%) was higher than those of the other samples, which ranged from $32.56 \%$ to $35.46 \%$. The $\mathrm{Al}_{2} \mathrm{O}_{3}$ content of sample AN (16.46\%) was significantly lower than those of samples KP $(36.25 \%)$, OP (36.23\%), and KA-II (29.43\%) [48]. The chemical compositions of the clay materials are shown in Table 1. Noor-ul-Amin et al. [47] studied the evaluation of clay as supplementary cementitious material and used chemical method with $\mathrm{CaCl}_{2} .2 \mathrm{H}_{2} \mathrm{O}$ to enhance the reactivity of the Pozzolanic and the mechanical properties of the final product. The chemical compositions of the clay materials are shown in Table 1.

Olofinnade et al. [51] showed that the particles should to be crushed and ground to the required fineness using a ball mill machine to activate the Pozzolanic behavior of the CB. Then, the particles were sieved through a $0.075 \mathrm{~mm}$ mesh. The chemical compositions of the cement and ground $\mathrm{CB}$ were determined by $\mathrm{X}$-ray fluorescence (XRF). The results indicated that the $\mathrm{SiO}_{2}$ content was $60.64 \%$, while the $\mathrm{Al}_{2} \mathrm{O}_{3}$ was approximately $14.23 \%$ (Table 1).
Rani [59] investigated the utilization of brick powder (BP) as a partial replacement of cementitious materials in concrete. The waste brick was crushed, ground to small particles, and then sieved through $90 \mu \mathrm{m}$. The $\mathrm{BP}$ contained $46.52 \% \mathrm{SiO}_{2}, 10.62 \%$ $\mathrm{Al}_{2} \mathrm{O}_{3}, 24.48 \%$ lime $(\mathrm{CaO})$, and $8.56 \% \mathrm{MgO}$ (Table 1 ).

Dobias and Pokorny [52] studied two different types of ground fired $\mathrm{CB}$ acid and lime bodies, and they showed different chemical compositions. Acid clay contained high $\mathrm{SiO}_{2}$ content of $73.64 \%$ and low $\mathrm{CaO}$ content of $1.29 \%$. CaO clay contains lower content of $\mathrm{SiO}_{2}$ of approximately $60.06 \%$ and relatively high percentage of $\mathrm{CaO}$ at $6.92 \%$ (Table 1 ).

Bediako [54] investigated the feasibility of using ground waste $\mathrm{CB}$ (GWCB) as supplementary cementitious material obtained from the brick factory in Ghana. The chemical analysis showed that the $\mathrm{SiO}_{2}$ content was $67.35 \%$ and the $\mathrm{Al}_{2} \mathrm{O}_{3}$ content was $14.7 \%$. ASTM C618 [60] states that for a potential suitable Pozzolanic, the summation of the $\mathrm{SiO}_{2}, \mathrm{Al}_{2} \mathrm{O}_{3}$, and $\mathrm{Fe}_{2} \mathrm{O}_{3}$ should be more than $70 \%$ [60]. The summation of oxides according to ASTM C 618 specification are illustrates in Table 2 .

Table 1: Chemical composition of clay materials according to previous studies.

Chemical compositions according to previous studies

\begin{tabular}{|c|c|c|c|c|c|c|c|c|c|c|}
\hline \multirow{3}{*}{ Oxide \% } & \multicolumn{10}{|c|}{ Chemical compositions according to previous studies } \\
\hline & \multicolumn{4}{|c|}{ [48] } & \multirow{2}{*}{$\begin{array}{c}{[47]} \\
\text { Clay materials } \\
\end{array}$} & \multirow{2}{*}{$\begin{array}{l}{[51]} \\
\mathrm{CB}\end{array}$} & \multirow{2}{*}{$\begin{array}{c}{[59]} \\
\text { BP }\end{array}$} & \multicolumn{2}{|c|}{ [52] } & \multirow{2}{*}{$\begin{array}{c}{[54]} \\
\text { GWCB }\end{array}$} \\
\hline & KA-II* & KP & AN & OP & & & & $\mathrm{A}$ & $\mathrm{L}$ & \\
\hline $\mathrm{SiO}_{2}$ & 54.13 & 32,56 & 16.46 & 34.4 & 58.4 & 60.64 & 42.52 & 73.64 & 60.06 & 67.35 \\
\hline $\mathbf{A l}_{2} \mathbf{O}_{3}$ & 29.43 & 36.25 & 16.46 & 36.23 & 28.7 & 14.23 & 10.62 & 13.58 & 16.21 & 14.7 \\
\hline $\mathrm{Fe}_{2} \mathrm{O}_{3}$ & 10.32 & 12.94 & 27.85 & 17.14 & 2.8 & 9.93 & 4.29 & 5.61 & 6.20 & 7.83 \\
\hline $\mathrm{CaO}$ & 2.31 & 3.78 & 2.25 & 3.7 & 0.28 & 0.27 & 24.48 & 1.29 & 6.92 & 2.19 \\
\hline MgO & - & - & - & - & 0.3 & 1.72 & 8.56 & 1.11 & 3.79 & 1.67 \\
\hline $\mathrm{SO}_{3}$ & - & - & - & - & - & - & 0.895 & 0.03 & 1.2 & 0.15 \\
\hline $\mathbf{K}_{2} \mathrm{O}$ & 2.23 & 13.44 & 15.89 & 7.22 & 0.2 & 1.44 & 1.84 & 2.51 & 3.08 & 1.21 \\
\hline MnO & 0.26 & 0.14 & 0.25 & 0.21 & - & - & 0.079 & - & - & - \\
\hline $\mathrm{TiO}_{2}$ & 1.14 & 0.67 & 1.48 & 0.84 & - & 0.98 & 0.51 & - & - & - \\
\hline $\mathbf{P}_{2} \mathbf{O}_{5}$ & - & - & - & - & - & 0.9 & 0.199 & - & - & - \\
\hline
\end{tabular}

*Note: KA-II: Kaikalathur; KP: Kuchipalayam; AN: Anangoor; OP: Ordinary Portland cement; CB: Clay Brick; BP: Brick Powder; A Acid clay; L;

Lime clay; GWCB: ground waste clay brick.

Table Error! No text of specified style in document.: Summation of the oxides Reference $\%$ Total of $\mathrm{SiO}_{2}, \mathrm{Al}_{2} \mathrm{O}_{3}$ and $\mathrm{Fe}_{2} \mathrm{O}_{3}$

\begin{tabular}{l|c}
\multicolumn{1}{c|}{$\quad$ Reference } & $\mathbf{\%}^{\mathbf{T}} \mathbf{T o t a l ~ o f ~} \mathbf{~ S i O}_{\mathbf{2}} \mathbf{A l}_{\mathbf{2}} \mathbf{O}_{\mathbf{3}}$ and $\mathbf{F e}_{\mathbf{2}} \mathbf{O}_{\mathbf{3}}$ \\
\hline (P SUDHA, 2015) KA-II [48] & 93.88 \\
\hline (P SUDHA, 2015) KP [47] & 81.75 \\
\hline (P SUDHA, 2015) AN [47] & 79.77 \\
\hline (P SUDHA, 2015) OP [48] & 87.77 \\
\hline (Bediako, 2018) GWCB [54] & 89.88 \\
\hline (Dobias and Pokorny, 2017) acid body [52] & 93.83 \\
\hline (Dobias and Pokorny, 2017) Lime body [52] & 82.47 \\
\hline (Olofinnade et al., 2016) CB [51] & 79.8 \\
\hline (M.Usha Rani, 2016) GCB [59] & 61.43 \\
\hline (Noor-ul-Amin, 2012) Pakistan clay [47] & 89.9 \\
\hline
\end{tabular}

\subsection{Influence on Fresh Properties}

Xianwei and Wang [61] examined the impacts of ground squander concrete (GWC) powder on the properties of crisp cement. The outcomes demonstrated that the smoothness of cement expanded straightly with the supplanting bond with GWC, and water request was diminished for the consistent consistency of concrete glue.

Wang et al. [49] decided the impact of CB powder (CBP). The outcomes demonstrated a noteworthy decrease in the droop test with over $10 \%$ substitution when bond Type I was utilized. This conduct caused by high water assimilation, unpleasant surface, and precision of CBP.

Mahdi et al. [50] explored the impact of fly fiery remains base slag on the functionality of cement. The outcomes showed diminished usefulness because of the usage of CBP as halfway or aggregate substitution of the fine total in cement. The CBP particles had unpredictable shape and harsh surface, which brought about expanded inward rubbing between particles. This marvel is in charge of the decreased pursue capacity of crisp cement.
Rani et al. [54] examined the impact of BP and diminished isolation and seeping in crisp cement. The outcomes demonstrated that the water content was kept up because of the expansion in the surface territory.

Olofinnade et al. [51] examined the functionality of new cement with $\mathrm{CB}$ halfway substitution, and the outcomes were kept roughly steady between $10 \%-20 \%$ bond supplanting and diminished with expanding level of CB substitution.

\subsection{Impact on thickness and mechanical properties}

This segment clarifies the impact of the supplanting concrete with $\mathrm{BP}$ or PC on the thickness and mechanical properties, for example, compressive, malleable. also, flexural quality.

\subsubsection{Thickness}

Wang et al. [49] contemplated the impact of CBP. The outcomes demonstrated that every solid example had comparable densities 
of roughly $2400-2500 \mathrm{~kg} / \mathrm{m} 3$ even with expanded substitution dimension of CBP.

Mahdi et al. [50] researched the impact of fly slag base powder on the thickness of cement. The outcomes demonstrated low thickness and high water retention.

Rani et al. [59] explored the impact of BP on the thickness of cement. The outcomes demonstrated an expansion in the thickness of cement because of the higher explicit gravity of BP than the solid segments. Block powder may fill the little voids causing an expanding in solid thickness. In reality, the bond powder has more explicit thickness than the block powder. Consequently, the solid thickness will be diminished when expanded the substitution.

Dobias and Pokorny [52], considered two unique kinds of ground terminated CB corrosive and lime bodies as added substances in $10 \mathrm{wt} \%$ of concrete. The outcomes demonstrate a slight decrease in the porosity of bond glue. In any case, when the added substance was $40 \mathrm{wt} \%$, an augmentation in the porosity of concrete glue was watched.

Olofinnade et al. [51] decided the impact of CBP on the thickness of cement. The test outcome demonstrated a decrease in the mass thickness of solidified concrete as the solid diminished contrasted and the typical cement.

\subsubsection{Compressive quality}

Amin et al. [46] reasoned that the substitution dimensions of $20 \%-30 \%$ of PC or CBP cause no noteworthy increment in the quality of bond mortar at 28 days. In any case, earth fineness expanded from $360 \mathrm{~m} 2 / \mathrm{kg}$ to $420 \mathrm{~m} 2 / \mathrm{kg}$.

Noor-ul-Amin et al. [47] found an augmentation in the compressive quality with $10 \%$ PC content, and the ideal grouping of $\mathrm{CaCl} 2.2 \mathrm{H} 2 \mathrm{O}$ was $4 \%$ to get the most extreme compressive quality of the bond mortar.

Sudha et al. [45] found that the compressive quality of synthetic initiated earth test was higher than that of the control at $2.5 \%$ substitution. The outcomes from compressive quality tests demonstrated that the mortar with $2.5 \%-12.5 \%$ substitution of KA-II and Operation and $2.5 \%-10 \%$ of KP had higher compressive quality than the control at 28 days. The mortar containing A had lower compressive quality than the control at 28 days, and the quality diminished as the earth content expanded,

Also, Wang et al. [49], considered the impact of CBP on the compressive quality of cement. The outcomes demonstrated that as the substitution level expanded, the early age quality diminished. Nonetheless, as the relieving age expanded, the compressive quality of cement with CBP was like that of the control concrete.

Rani [59] and Olofinnade et al. [51] found around similar outcomes in compressive quality. The compressive quality expanded up to $10 \%$ and $20 \%$ supplanting of GCB contrasted and the control concrete [59]. All CB concrete indicated noteworthy enhancement in compressive quality at 28 days contrasted and the control. At 28 days, a huge enhancement in compressive quality was seen at $10 \%$ CB substitution, trailed by a steady decrease in quality.

Dobias and Pokorny [52] contemplated two distinct kinds of ground terminated CB corrosive and lime bodies. The outcomes demonstrated that compressive quality was not antagonistically influenced with $10 \%-20 \%$ supplanting concrete with GB, while at times the enlarged mortars achieved higher quality than the control mortar at all tried ages from 28 days to 84 days. This conduct might be because of huge change in the aggregate porosity of mortar examples.
Khan et al. [53] demonstrated that 5\% and 10\% BP will in general increment the quality of cement, however the quality of substitution at $10 \%$ was under $5 \%$ of the quality at 7,14 , and 28 days

Bediako [54] presumed that the compressive qualities for all mortar blends expanded with relieving period. The quality execution showed that the ideal mortar blend was utilizing Portland bond supplanting with GWCB at 30wt\%.

\subsubsection{Rigidity}

The rigidity announced in this investigation was from the investigation of Sudha et al. [48]. The outcomes demonstrated that $2.5 \%$ substitution level brought about ideal quality, and the earth tests displayed preferable outcomes over the control example up to substitution dimension of $10 \%$. Be that as it may, expanding mud up to $20 \%$ negatively affected the split elasticity of the concrete mortar.

Wang et al. [49] presumed that the rigidity for 28 days was 5,4, and 3.7 $\mathrm{MPa}$ at substitution dimensions of $10 \%, 20 \%$, and $30 \%$ separately.

Rani [59] found that the part elasticity expanded in the example with up to $10 \%$ and $20 \%$ supplanting of GCB contrasted and that of the control.

Olofinnade et al. [51] announced an expansion in quality for up to $10 \%$ supplanting of bond with CB. At that point, the quality of the solid diminished marginally for the 28 days restored test.

\subsubsection{Flexural quality}

The example indicated preferred flexural quality over the control example at substitution dimension of $2.5 \%$ yet diminished at the substitution dimension of over than $2.5 \%$ to $20 \%$ [48]

Supplanting of concrete with GB by $10 \%-20 \%$ does not contrarily influence the flexural of the test examples of mortar [52]. The flexural quality expanded in the example with up to $10 \%$ and $20 \%$ supplanting of GCB contrasted and the control concrete [59]. The scope of the flexural quality for 28 days was $10-12 \mathrm{MPa}$ at substitution dimensions of $10 \%, 20 \%$, and $30 \%$ [49].

\subsection{Morphology by X-beam diffraction (XRD) and checking electron microscopy (SEM)}

A few examinations explored the concrete glue with PC utilizing XRD and SEM. Sanchez de Rojas [52] mixed clay squanders with bond and relieved the examples at $40{ }^{\circ} \mathrm{C}$. XRD results indicated little measures of calcium aluminate stages that couldn't be found in the control blend.

Fernandez [63] saw that the SEM pictures can give a diagram of the microstructural morphology of hydration segments. The quantitative results of hydrated concrete glue with calcined earth gave the pore framework expected to cutting edge strategies, for example, mercury interruption porosimetry, to clarify the pore measure conveyance, add up to porosity, and network.

Dhandapani and Santhanam [64] created a viable low clinker bond mix by consolidating calcined earth and limestone. The hydrate stage was considered by XRD. The outcomes showed that the decrease in the porosity in the hydrated bond glue was because of the more prominent measure of hydrate items. In addition, the assessed porousness of the bond glue with calcined mud and limestone accomplished much lower penetrability contrasted and the customary Portland concrete with $30 \%$ fly fiery remains.

Du and Dai Ache [3] thought about the microstructural perceptions in OPC mortar and mortar with $30 \%$ OPC supplanted by 
calcined marine dirt. The outcomes demonstrated that calcined earth grain furnished an extremely thick security with its encompassing hydration items (Fig. 2). The adjustment in the morphology microstructure was extraordinarily apparent in the SEM pictures, which concur well with the XRD results.
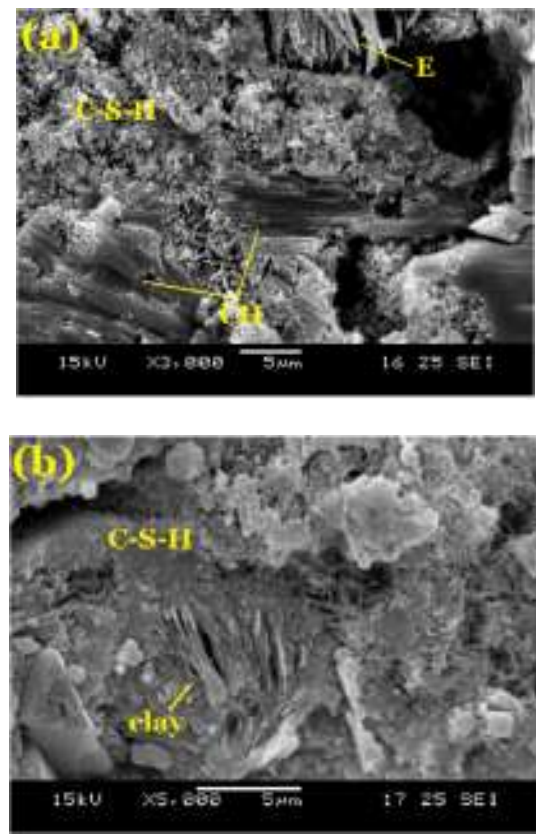

Fig. 2:. Microstructures of (a) OPC and (b) calcined marine clay mortar at 28 days. (C-S-H: calcium silica hydrates, $\mathrm{CH}$ : Portlandite, E: ettringite) [3].

\section{Conclusion}

This article reports a review of the use of PC or CBP in concrete mixtures. The following conclusions can be drawn:

The strength activity index of PC at 7 and 28 days satisfied the standard specifications of the ASTM C618 for Pozzolanic materials. Therefore, the enhanced strength gains of PC-cement blend are beneficial than the control mixes. The workability with increasing percentage of replacement of cement with clay materials was reduced compared with the control concrete. The porosity of concrete increased with higher percentages of replacement. The results showed a reduction in the bulk density and in some cases undergone increment due to increase in specific gravity of clay materials. Therefore, PC powder has an effect on the strength of concrete (compressive, splitting, and flexural strength). The results indicated

that the optimum strength for replacing Portland cement with PC was at $10 \mathrm{wt} \%-30 \mathrm{wt} \%$. The following research needs can be drawn from the presented review:

1.The long-term performance of concrete with PC when exposed to high temperatures, as well as its durability, should be evaluated. 2.Most of the available studies evaluated the performance of concrete with PC based on laboratory tests. Therefore, the performance should be verified using real site tests to facilitate the further application of PC in the industry in an eco-friendly and sustainable way.

3.The resistance of PC concrete to the corrosion of the embedded steel reinforcements and alternative freeze-thaw studies on PC concrete should be investigated.

4.PC concrete with fiber reinforcement (e.g., carbon, steel, polypropylene, and glass) can provide give new insights to this research.

\section{References}

[1] Hansford, M., (2018). "Urgent call to action for civil engineers. N Civ. Eng. 32e35.
[2] He, C., Makovicky, E., Osbaeck, B., (1994). "Thermal stability and pozzolanic activity of calcined kaolin", Appl. Clay Sci. 9, 165e187.

[3] Du, H., \& Dai Pang, S. (2018). "Value-added utilization of marine clay as cement replacement for sustainable concrete production", Journal of Cleaner Production, 198, 867-873.

[4] V.M. Malhotra, P.K. Mehta, (1996), "Pozzolanic and Cementitious Materials", Gordon \&Breach Publishers, Amsterdam.

[5] Moayad N. Al-Khalaf, Hana A. Yousif, (1984), "Use of rice husk ash in concrete", Int. J.Cem. Compos. Lightweight Concrete 6 (4) 241-248.

[6] Gemma Rodríguez de Sensale, (2006), "Strength development of concrete with rice husk ash", Cement and Concrete Compos. 28 (2) $158-160$.

[7] Shazim Ali Memon, Muhammad Ali Shaikh, Hassan Akbar, (2008), "Production of low cost self-compacting concrete using rice husk ash, in: First International Conference on Construction in Developing Countries (ICCIDC-I) "Advancing and Integrating Construction Education, Research \& Practice" August 4-5, Karachi, Pakistan.

[8] A. Ramezanianpour, M. Mahdi khani, Gh. Ahmadibeni, (2009), "The effect of rice husk ash on mechanical properties and durability of sustainable concretes", Int. J. Civ. Eng. 7 (2) 83-91.

[9] Alireza Naji Givi, Suraya Abdul Rashid, A. Aziz, Farah Nora, Mohamad Amran Mohd Salleh, (2010), Contribution of rice husk ash to the properties of mortar and concrete: a review, J. Am. Sci. 6 (3) $157-165$.

[10] V. Ramasamy, (2012), "Compressive strength and durability properties of Rice Husk Ash concrete", KSCE J. Civ. Eng. 16 (1) 93 102.

[11] R.N. Krishna, (2012), "Rice Husk Ash - an ideal admixture for concrete in aggressive environments", in: 37th Conference on Our World in Concrete \& Structures, 29-31 August, Singapore.

[12] Godwin A. Akeke, Maurice E. Ephraim, I.Z.S. Akobo, Joseph O. Ukpata, (2013), "Structural properties of rice husk ash concrete, Int. J. Eng. Appl. Sci. 3 (3) 57-62.

[13] Jayanti Rajput, R.K. Yadav, R. Chandak, (2013), "The effect of rice husk ash used as supplementary cementing material on strength of mortar", Int. J. Eng. Res. Appl. 3 (3) 133-136.

[14] R.N. Tarun, N.K. Rudolph, S. Rafat, Use of Wood Ash in Cementbased Materials, A CBU Report, CBU-2003-19 (REP-513), http://uwm.edu/Dept/CBU/ report.

[15] Shahiron Shahidan, B.A. Tayeh, AA Jamaludin, NAAS Bahari, SS Mohd, N Zuki Ali, FS Khalid, (2017) Physical and mechanical properties of self-compacting concrete containing superplasticizer and metakaolin. IOP Conference Series: Materials Science and Engineering. 271, 01, 1-7.

[16] M. Abdullahi, (2003), "Characteristics of Wood ASH/OPC Concrete", Civil Engineering Department, Federal University of Technology. P.M.B. 65, Minna, Niger State, Nigeria.

[17] Abdullah M Zeyad, B.A. Tayeh, Abdalla M. Saba, Megat A Megat Johari, (2018) Workability, Setting and Strength of HighStrengthConcrete Containing High Volume of Palm Oil Fuel Ash. The Open Civil Engineering Journal. 12, 3, 35-46.

[18] M. Abdullahi, Characteristics of wood ASH/OPC concrete, Leonardo Electron. Pract. Technol. 8 (2006) 9-16. ISSN 1583-107.

[19] Abdullah M Zeyad, Megat A Megat Johari, B.A. Tayeh, Moruf O Yusuf, (2017) Pozzolanic reactivity of ultrafine palm oil fuel ash aste on strength and durability performances of high strength concrete. Journal of Cleaner Production. 144, 511-522.

[20] Chee Ban Cheah, Mahyuddin Ramli, (2011), "The implementation of wood waste ash as a partial cement replacement material in the production of structural grade concrete and mortar: an overview", Resour. Conserv. Recycl. 55 (7) 669-685.

[21] AM Zeyad, MA Megat Johari, B.A. Tayeh, Moruf Olalekan Yusuf, (2016) Efficiency of treated and untreated palm oil fuel ash as a supplementary binder on engineering and fluid transport properties of higstrength concrete. Construction and Building Materials. 125, 1066-1079

[22] Mohammed, A.N., Megat Johari, M.A. \& Zeyad A.M. B.A. Tayeh \& Yusuf, M.O. (2014). Engineering and Fluid Transport Properties of Ultra-High Strength Concrete Utilizing Ultrafine Palm Oil Fuel Ash. Journal of Advanced Concrete Technology, 12, 127-1137.

[23] A. Raheem, B.S. Olasunkanmi, C.S. Folorunso, Saw dust ash as partial replacement for cement in concrete, Organ. Technol. Manage. Constr. Int. J. 4 (2) (2012) 474-480.

[24] Tayeh, B. A., \& Al Saffar, D. M. (2018). Utilization of Waste Iron Powder as Fine Aggregate in Cement Mortar. Journal of Engineering Research and Technology, 5(2). 
[25] Shehdeh,G., HusamN., and RosaV.,"Experimental study of concrete made with granite and iron powders as partial replacement of sand",ustainable Materials and Technologies, Volume 9, September 2016, Pages 1-9.

[26] Quiroga, P. N., Ahn, N., \& Fowler, D. W. (2006). Concrete mixtures with high microfines. ACI materials journal, 103(4), 258.

[27] De Larrard, F. (2014). Concrete mixture proportioning: a scientific approach. CRC Press. london, 320pp.

[28] Bigas, J. P., \& Gallias, J. L. (2002). Effect of fine miner-al additions on granular packing of cement mixtures. Mag-azine of Concrete Research, 54(3), 155-164.

[29] Kim, H., Haas, C. T., Rauch, A. F., \& Browne, C. (2002). Dimensional ratios for stone aggregates from three-dimensional laser scans. Journal of computing in Civil Engineering, 16(3), 175-183.

[30] Kuo, C. Y., Frost, J., Lai, J., \& Wang, L. (1996). Three-dimensional image analysis of aggregate particles from orthogonal projections. Transportation Research Record: Journal of the Transportation Research Board, (1526), 98-103.

[31] Ismail Z. Z. and AL-Hashmi E. A., (2008), "Reuse of waste iron as a partial replacement of sand in concrete," Waste Management, vol. 28, no. 11, pp. 2048-2053.

[32] Bassam A. Tayeh, (2018). Investigation the effect of marble, timber and glass powder as a partial replacement of cement. Journal of Civil Engineering and Construction 7, 02, 63-71.

[33] Zhao S., Fan J., and Sun W., (2014), "Utilization of iron ore tailings as fine aggregate in ultra-high performance con-crete," Construction and Building Materials, vol. 50, pp. 540-548.

[34] Alwaeli and J. Nadziakiewicz, (2012), "Recycling of scale and steel chips waste as a partial replacement of sand in con-crete," Construction and Building Materials, vol. 28, no. 1, pp. 157-163.

[35] Ahmed S.O., Hamdy A. Abdel-G., (2017), " The effect of replacing sand by iron slag on physical, mechanical and radiological properties of cement mortar", HBRC Journal, Volume 13, Issue 3, December, Pages 255-261.

[36] Wang, H. Y., Zeng, h. H., \& Wu, Y. J., (2014), "A study on the macro and micro properties of concrete with LCD glass". Construction and Building Materials, 50, 664-670.

[37] Wang, H. Y., \& Huang, W. L., (2010), "Durability of selfconsolidating concrete using waste LCD glass". Construction and Building Materials, 24, 1008-1013.

[38] Taha, B., \& Nounu, G. (2008), "Properties of concrete contains mixed color waste recycled glass". Construction and Building Materials, 22, 713-720.

[39] Limbachiya, M. C., (2009), "Bulk engineering and durability properties of washed glass sand concrete". Construction and Building Materials, 23, 1078-1083.

[40] Ali, E. E., \& Al-Tersawy, S. H. (2012), "Recycled glass as a partial replacement for fine aggregate in self". Construction and Building Materials, 35, 785-791.

[41] Kou, S. \& Poon, C., (2009), "Properties of Self-Compacting Concrete Prepared with Recycled Glass Aggregate". Cement and Concrete Composites, Volume 31, pp. 107-113; 2009.

[42] M. Adaway \& Y. Wang, (2015), "Recycled glass as a partial replacement for fine aggregate in structural concrete - Effects on compressive strength". Electronic Journal of Structural Engineering.

[43] Al Saffar, Doha Mothefer Abdul-Razzaq. (2017), "Experimental Investigation of Using Ultra-Fine Glass Powder in Concrete." Int. Journal of Engineering Research and Application,Vol. 7, Issue 9, (Part -8), pp.33-39.

[44] Sivakumar, A., and Prakash, M., (2011), "Characteristic Studies on the Mechanical Properties of Quarry Dust Addition in Conventional Concrete," Journal of Civil Engineering and Construction Technology, V. 2, No. 10, Oct., pp. 218-235.

[45] A. Muthadhi and V. Dhivya. (2017), "Investigating Strength Properties of Geo Polymer Concrete with Quarry Dust", ACI materials Journal, May-June, V. 114, No. 3, pp. 355.

[46] Amin, n. u., alam, s., gul, s. \& muhammad, k., (2012), " Activation of clay in cement mortar applying mechanical, chemical and thermal techniques", Advances in cement research, 24, 319-324.

[47] Noor-ul-amin, (2012), "Use of clay as a cement replacement in mortar and its chemical activation to reduce the cost and emission of greenhouse gases", Construction and building materials, 34, 381 384.

[48] P sudha, r. S. A. T. P., (2015)," Experimental studies on cement mortar for partial replacement of cement by chemically activated clay", International journal of earth sciences and engineering., 08.
[49] Ge, z., wang, y., sun, r., wu, x. \& guan, y., (2015), "Influence of ground waste clay brick on properties of fresh and hardened concrete", Construction and Building Materials, 98, 128-136.

[50] Mahdi rafieizonooz, j. M., mohd razman salim, mohd warid hussin and elnaz khankhaje,.(2016), "Investigation of coal bottom ash and fly ash in concrete as replacement for sand and cement", Elsevier, 10,10 .

[51] Olofinnade, o. M., ede, a. N., ndambuki, j. M. \& bamigboye, g. O., (2016), "Structural properties of concrete containing ground waste clay brick powder as partial substitute for cement", In: materials science forum, Trans tech publ, 63-67.

[52] Dobias, d. \& pokorny, P., (2017), "Influence of Partial Replacement of Hydraulic Binder by Ground Brick on the Characteristics of Composites. Procedia engineering," 190, 568-574.

[53] Khan, m. M., panchal, s., sharma, a. \& bharti, a. A., (2017), "Innovative use of brick powder and marble dust as a mineral admixture in concrete", International journal of civil engineering and technology, 8.

[54] Bediako, m., (2018), "Pozzolanic potentials and hydration behavior of ground waste clay brick obtained from clamp-firing technology", Case Studies in Construction Materials, 8, 1-7.

[55] Manning D, Bergaya F, Theng BKG, Lagaly GE. (2007), "Handbook of clay science - developments in clay science", Elsevier Science \& Technology:19-86.

[56] Anderson RL, Ratcliffe I, Greenwell HC, Williams PA, Cliffe S, Coveney PV. (2010) "Clay swelling - a challenge in the oilfield", Earth Sci Rev;98: 201-16.

[57] Nehdi, M. L. (2014), "Clay in cement-based materials: Critical overview of state-of-the-art", Construction and Building Materials, 51, 372-382.

[58] Fernandes, F. M., Lourenço, P. B., \& Castro, F. (2010). Ancient clay bricks: manufacture and properties. In Materials, Technologies and Practice in Historic Heritage Structures (pp. 29-48). Springer, Dordrecht.

[59] M.usha rani, J. M. J. (2016). Mechanical properties of concrete with partial replacement of Portland cement by clay brick powder. IJERT, 5, 5 .

[60] ASTM C618 - 17a, 2010.Standard Specification for Coal Fly Ash and Raw or Calcined Natural Pozzolan for Use in Concrete.

[61] Ma, X., \& Wang, Z. (2013). Effect of ground waste concrete powder on cement properties. Advances in Materials Science and Engineering.

[62] M. I. Sanchez de Rojas, F. Marin, J. Rivera and M. Frias, Morphology and Properties in Blended Cements with Ceramic Wastes as a Pozzolanic Material, Journal of the American ceramics society 89 (2006) 3701.

[63] Fernandez, R., 2016. Calcined Clayey Soils as a Potential Replacement for Cement in Developing Countries. PhD thesis. EPFL.

[64] Dhandapani, Y., Santhanam, M., (2017). Assessment of pore structure evolution in the limestone calcined clay cementitious system and its implications for performance. Cement Concr. Compos. 84, $36 \mathrm{e} 47$.

[65] https://es.123rf.com/photo_7511778_textura-desde-los peque $\% \mathrm{C} 3 \% \mathrm{~B} 1$ os-trozos-de cer\%C3\%A1 mica-rota-.html. 